\title{
Cone Beam Computed Tomographic Analysis of Paranasal Variations, Osteomeatal Complex Disease, Odontogenic Lesion and Their Effect on Maxillary Sinus
}

\author{
Paranazal Varyasyonların, Osteomeatal Kompleks Hastalığının \\ ve Odontojenik Lezyonların Maksiller Sinüse Olan Etkisinin Konik \\ Işınıı Bilgisayarlı Tomografi ile Incelemesi \\ (D) Emre Köse ${ }^{1}$, (1) Emin Murat Canger ${ }^{2}$, (1) Duygu Göller Bulut ${ }^{3}$
}

${ }^{1}$ Aydın Adnan Menderes University Faculty of Dentistry, Department of Oral and Maxillofacial Radiology, Aydın, Turkey

${ }^{2}$ Erciyes University Faculty of Dentistry, Department of Oral and Maxillofacial Radiology, Kayseri, Turkey

${ }^{3}$ Bolu Abant İzzet Baysal University Faculty of Dentistry, Department of Oral and Maxillofacial Radiology, Bolu, Turkey

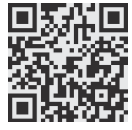

Keywords

Concha bullosa, nasal septal deviation, maxillary sinus mucosal thickening, odontogenic lesions, cone beam computed tomography

\section{Anahtar Kelimeler}

Konka bulloza, nazal septum deviasyonu, maksiller sinüs mukozal kalınlaşması, odontojenik lezyon, konik ışınlı bilgisayarlı tomografi

Received/Geliş Tarihi : 27.09.2017

Accepted/Kabul Tarihi : 03.09.2018

doi:10.4274/meandros.58561

Address for Correspondence/Yazışma Adresi: Emre Köse MD,

Aydın Adnan Menderes University Faculty of Dentistry, Department of Oral and Maxillofacial Radiology, Aydın, Turkey

Phone : +90 5308238935

E-mail : emre.kose@adu.edu.tr

ORCID ID: orcid.org/ 0000-0002-0659-7157

(C) Meandros Medical and Dental Journal, Published by Galenos Publishing House.

This is article distributed under the terms of the

Creative Commons Attribution NonCommercial 4.0

International Licence (CC BY-NC 4.0).

\begin{abstract}
Objective: The objective of this study was to establish the prevalence of nasal septal deviation, concha bullosa, and osteomeatal complex disease (obstruction), and odontogenic lesions, along with their potential relationships with maxillary sinus mucosal thickening.

Materials and Methods: (CBCT) images of 200 patients (101 males, 99 females) with 396 exposed maxillary sinuses, were inspected for presence of nasal septal deviation, concha bullosa, osteomeatal complex disease (obstruction), and odontogenic lesions related to maxillary sinus and maxillary sinus mucosal thickening.

Result: One hundred nineteen patients (59\%) had nasal septal deviation, 100 (50\%) had at least one concha bullosa, 26 (13\%) had osteomeatal complex disease on at least one side, 39 (19.5\%) had odontogenic lesions related to maxillary sinuses, and $112(56 \%)$ had evidence of mucosal thickening. There was a statistically significant relationship among osteomeatal complex disease, odontogenic lesion and maxillary sinus mucosal thickening $(p=0.00)$. No statistically significant relationship could be established among the presence of concha bullosa, nasal septal deviation and maxillary sinus mucosal thickening ( $p>0.05)$.

Conclusion: Odontogenic lesions and osteomeatal complex diseases have association with maxillary sinus mucosal thickening. CBCT imaging could be a diagnostic tool for assessment potential reasons of maxillary sinus mucosal thickening.
\end{abstract}

Öz

Amaç: Bu çalışmanın amacı nazal septum deviasyonu, konka bulloza, osteomeatal kompleks tıkanıklığı ve odontojenik lezyon varlığının, maksiller sinüs mukozal kalınlaşmasıyla olan potansiyel ilişkisinin ortaya konmasıdır.

Gereç ve Yöntemler: İki yüz hastaya (101 erkek, 99 kadın) ait 396 maksiller sinüsün konik ışınlı bilgisayarlı tomografi görüntülerinde; maksiller sinüs mukozal kalınlaşmasıyla ilişkili nazal septum deviasyonu, konka bulloza, osteomeatal kompleks tıkanıklığı ve odontojenik lezyon varlığına bakıımıştır.

Bulgular: Yüz on dokuz hastada (\%59) nazal septal deviasyon, 100 hastada (\%50) en az bir konka bulloza, 26 hastada (\%13) en az bir tarafta osteomeatal kompleks 
hastalığı, 39 hastada $(\% 19,5)$ maksiller sinüsle ilişkili odontojenik lezyon ve 112 hastada $(\% 56)$ mukozal kalınlaşma tespit edilmiştir. Osteomeatal kompleks hastalığı ve odontojenik lezyon ile maksiller sinüs mukozal kalınlaşması arasında istatistiksel olarak anlamlı ilişki bulunmuştur $(p=0,00)$. Konka bulloza ve nazal septum deviasyonu ile maksiller sinüs mukozal kalınlaşması arasında istatistiksel olarak anlamlı ilişki bulunmamıştır ( $p>0,05)$.

Sonuç: Odontojenik lezyon ve osteomeatal kompleks hastalığı ile maksiller sinüs mukozal kalınlaşması arasında ilişki bulunmuştur. Konik ışınlı bilgisayarlı tomografi görüntüleme maksiller sinüste mukozal kalınlaşmaya neden olan potansiyel etmenleri belirlemede tanı aracı olabilir.

\section{Introduction}

Maxillary sinuses are air-filled spaces located at the lateral of the nasal cavity and are connected with it through an ostium. They are extending to the apexes of posterior teeth inferiorly. Odontogenic lesions (OL) with close proximity to sinuses such as granulomas, cysts and periodontitis can cause odontogenic maxillary sinusitis (OMS). MS can occur when mucosal membrane of sinuses is irritated by extention of pulp infecton or chronic infection and destruction of tooth socket (1). Maxilary sinusitis is caused by temporary and/or reversible mucociliary dyskinesia (2), which could be caused by some osteomeatal obstructions, allergy, and among other conditions, as well as abnormal growths, such as nasal septal deviations (NSD), concha bullosa (CB) (3-7). Maxillary sinus mucosal thickening (MT) is the radiographical appearance of MS, defined as inflammation of maxillary sinuses (2).

Osteomeatal complex is a term referring to the maxillary sinus ostium, ethmoidal infundibulum, hiatus semilunaris and frontal recess. It is a common channel that links the frontal sinus, anterior and middle ethmoid sinuses and the maxillary sinus to the middle meatus that allows air flow and mucociliary drainage (8). Osteomeatal complex disease (OMD) is an inflammatory mucosal disease which affects the anterior ethmoid cells, the ethmoid infundibulum, and the drainage pathways leading to the middle meatus. Anatomic variations can narrow or block pathways which resulting OMD. Opening the obstruction could result in an improvement of the MS. It is generally believed that OMD, which have strong relationship with septal deviation, may impede ventilation and mucociliary clearance from the sinuses, thus predisposing the affected individual to sinusitis $(9,10)$.

$\mathrm{CB}$ is a pneumatized cavity of the concha, which is one of the most frequent variations of nasal cavity also known as a middle turbinate pneumatization. Bolger et al. (11) have classified pneumatization of the concha according to the site as bulbous CB (pneumatization of the bulbous part), lamellar CB (pneumatization of the vertical part) and extensive $\mathrm{CB}$ (pneumatization of both lamellar and bulbous parts) (12). It may leads to MS by the obstruction of the middle meatus (13-15).

Computed tomography (CT) is a standard radiographic modality for accurately assessment mucosal changes and variations of nasal cavity and paranasal sinuses. With the growing use of cone beam $\mathrm{CT}$ (CBCT) which has lower radiation dose compared with $\mathrm{CT}$, dentists/maxillofacial radiologists and otolaryngologists are more able to define pathological conditions and anatomical aberrancies within the tissues of the sinonasal structures $(11,16)$.

The aim of this study is to determine the prevalence of $C B, N S D, O M D$, and $O L$ and examine their potential relationship with $\mathrm{MT}$.

\section{Materials and Methods}

The Ethical Committee of the University of Erciyes approved the study protocol (approval no: 2017/440, date: 15.09.2017) that has, therefore, performed in accordance with ethical standards laid down in the Declaration of Helsinki in 1964.

This retrospective study utilized the CBCT (Newtom 5G, QR, Verona, Italy, $110 \mathrm{kVp}$ and $0.57 \mathrm{~mA} 12-18 \mathrm{~s}$, $0.25 \mathrm{~mm}$ isotropic voxel size) images of subjects who were referred to our clinic, because of some dental problems (implant planning, cysts, impacted teeth). All CBCT images were evaluated by the same radiologist who has experience in assessing CBCT volumetric data.

The inclusion criteria:

1. Good quality of the CBCT images,

2. Good visibility of both maxillary sinuses with selected field of view (fov),

3. Bilateral existence of at least one of maxillary posterior tooth. 
The exclusion criteria:

1. Evidence of trauma or developmental anomalies on CBCT images,

2. Subjects with mucosa thickening of all sinus walls,

3. Subjects with a history of prior nasal or sinus surgery.

CBCT images of 200 subjects (99 females and 101 males) were utilized. The images were examined in a darkroom, using the inbuilt software (NNT) in a Dell Precision T5400 workstation (Dell, Round Rock, TX, USA), with a 32-inch Dell LCD screen of $1.280 \times 1.024$ pixels resolution. The contrast and brightness of the images were adjusted using the image processing tool provided as a part of the software, to ensure optimal visualization.

Scans were reviewed for sinonasal region abnormalities and pathologies, with specific evaluation on the presence of CB and its types, NSD, $\mathrm{OL}, \mathrm{OMD}$ and MT. CB was defined and classified as the presence of pneumatization of the superior, middle or inferior turbinates $(13,16)$. Deviation of the nasal septum was defined as a deviation of more than $4 \mathrm{~mm}$ from the midline (16). Presence of pneumatization of the nasal septum was also investigated. Each of the maxillary sinuses and osteomeatal obstructions were assessed separately. Presence of MTs exceeding $2 \mathrm{~mm}$ was defined as MT $(16,17)$. Teeth with apical lesions (granulomas, cysts), which were in contact with or exposed the sinus floor, were identified and their respective sides recorded (Figure 1a-f).

\section{Statistical Analysis}

Statistical analysis was performed by SPSS 16.0 for Windows (SPSS, Chicago, IL) to determine the prevalence of NSD, type of CB, MS, OMD, and OL. Categorical variables were shown, along with their respective percentage values, and were compared using the $\chi^{2}$ tests. For this purpose, $p<0.05$ was considered as statistically significant.

\section{Results}

CBCT images of 396 sides of 200 patients were examined. Ninety-nine $(49.5 \%)$ of them were female and 101 (50.5\%) were male.

Osteomeatal complex disease: OMD was present in 26 subjects. Seven were on the left side, 9 on the right side, and 10 were bilaterally. While 22 were male, the number of female was 4 . There was statistically significant difference in accordance to gender $(p=0.00)$ (Tables 1, 2)

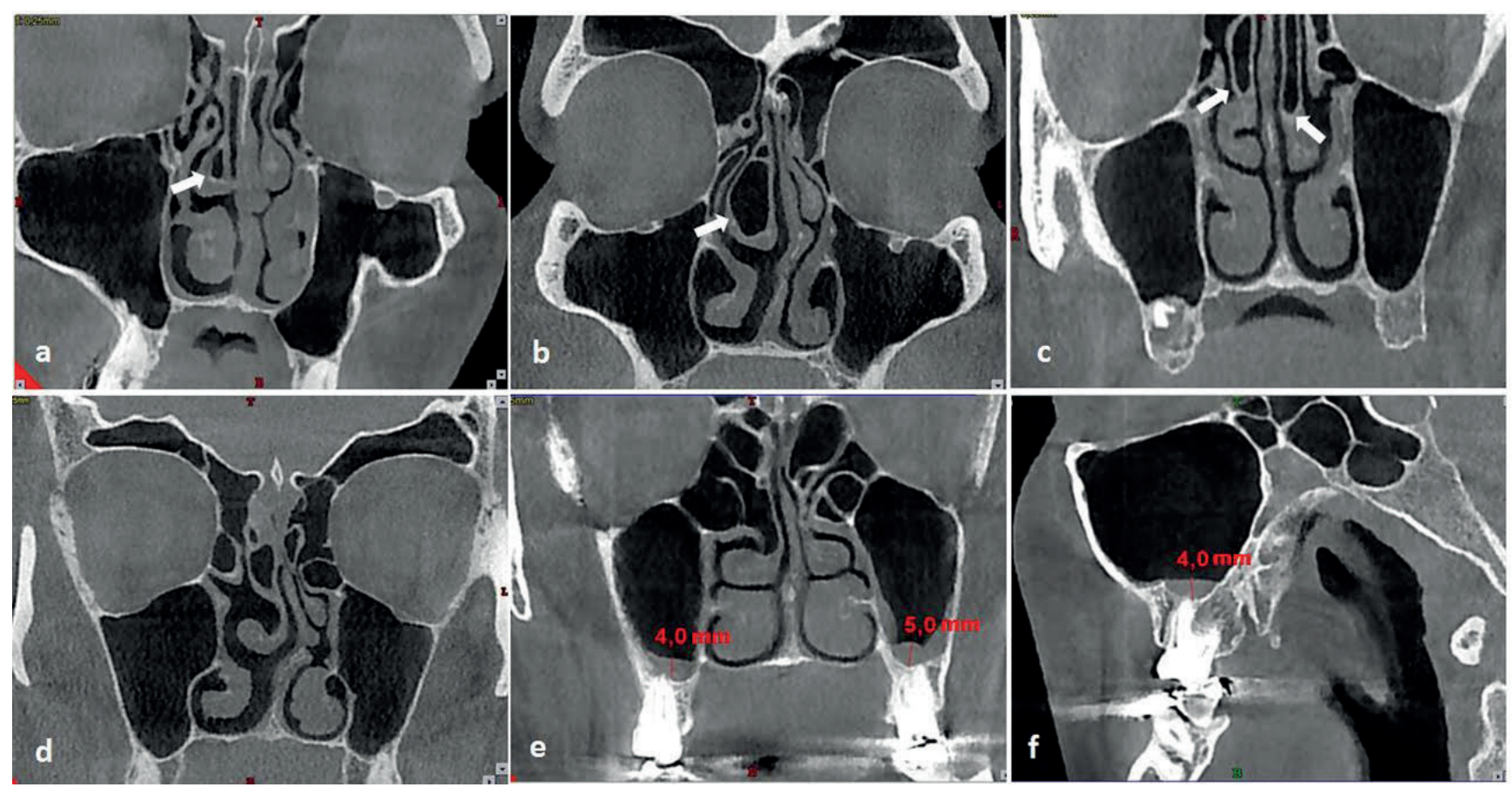

Figure 1. a) Bulbous type of concha bullosa, b) Extensive type of concha bullosa, c) Lamellar type of concha bullosa, d) Left sided septal deviation, e, f) mucosal thickening related with odontogenic lesion 


\begin{tabular}{|c|c|c|c|c|c|c|c|c|c|c|}
\hline Condition & \multicolumn{2}{|c|}{$\begin{array}{c}\text { Osteomeatal complex } \\
\text { disease }\end{array}$} & \multicolumn{2}{|c|}{ Concha bullosa } & \multicolumn{2}{|c|}{ Nasal septal deviation } & \multicolumn{2}{|c|}{ Odontogenic lesion } & \multicolumn{2}{|c|}{ Mucosal thickening } \\
\hline Gender & Present & Absent & Present & Absent & Present & Absent & Present & Absent & Present & Absent \\
\hline Female & $22(84.6 \%)$ & 79 (45.4\%) & 45 (45\%) & $56(56 \%)$ & 69 (57.9\%) & $31(38.2 \%)$ & $23(58.9 \%)$ & 78 (48.4\%) & $64(57.1 \%)$ & $37(42 \%)$ \\
\hline Male & $4(15.4 \%)$ & 95 (54.6\%) & $55(55 \%)$ & $44(44 \%)$ & $50(42 \%)$ & $50(61.7 \%)$ & $16(41 \%)$ & $83(51.6 \%)$ & 48 (42.9\%) & $51(58 \%)$ \\
\hline Total & $26(13 \%)$ & $174(87 \%)$ & $100(50 \%)$ & $100(50 \%)$ & 119 (59\%) & $81(41 \%)$ & 39 (19.5\%) & $161(80.5 \%)$ & $112(56 \%)$ & 88 (44\%) \\
\hline
\end{tabular}

Table 2. Distribution of the pathological conditions according to the effected side

\begin{tabular}{|c|c|c|c|c|c|c|c|c|c|c|}
\hline Condition & \multicolumn{2}{|c|}{$\begin{array}{l}\text { Osteomeatal complex } \\
\text { disease }\end{array}$} & \multicolumn{2}{|c|}{$\begin{array}{l}\text { Concha } \\
\text { bullosa }\end{array}$} & \multicolumn{2}{|c|}{$\begin{array}{l}\text { Nasal septal } \\
\text { deviation }\end{array}$} & \multicolumn{2}{|c|}{$\begin{array}{l}\text { Odontogenic } \\
\text { lesion }\end{array}$} & \multicolumn{2}{|c|}{$\begin{array}{l}\text { Mucosal } \\
\text { thickening }\end{array}$} \\
\hline Effected side & $n$ & (\%) & $n$ & (\%) & $n$ & (\%) & $n$ & (\%) & $n$ & (\%) \\
\hline Left side & 7 & 26.9 & 10 & 10 & 63 & 52.9 & 8 & 20.5 & 18 & 16 \\
\hline Right side & 9 & 34.6 & 35 & 35 & 56 & 47.1 & 16 & 41 & 33 & 29.5 \\
\hline Bilateral & 10 & 38.5 & 55 & 55 & - & - & 15 & 38.5 & 61 & 54.5 \\
\hline Total & 26 & 100 & 100 & 100 & 119 & 100 & 39 & 100 & 112 & 100 \\
\hline
\end{tabular}

Concha bullosa: CB was observed in $100(50 \%)$ of the subjects ( 55 female and 45 male). All were noted in the middle concha. Of the $155 \mathrm{CBs}, 10$ were seen only in the left, 35 were located only in the right, and in 55 were detected bilaterally. Reverse curvature and absence of concha were not detected. Bulbous CB was found in 48 cases, extensive type $C B$ in 8 cases, and lamellar CB in 99 cases. (Figure 1a-c) There was no significant statistical difference in accordance to gender ( $p>0.05$ ) (Tables 1, 2).

Nasal septal deviation: NSD was found in 119 (59.5\%) cases ( 50 female and 69 male). Pneumatisation of nasal septum was not detected. Left-sided deviation was found in $63(15.9 \%)$ cases, and rightsided deviation of the nasal septum was found in 56 (14.5\%) cases (Figure 1d). In accordance to gender, no significant statistical difference was found $(p>0.05)$ (Tables 1, 2).

Odontogenic lesion: Fifty- four OLs were detected in $39(19.5 \%)$ of all cases (16 female and 23 male). Eight (20.5\%) were at the left, $16(41 \%)$ were at the right and 15 (38.5\%) were present bilaterally $(p>0.05)$ (Tables 1, 2).

Maxillary sinus mucosal thickening: In 112 (56\%) of cases MT was detected (48 female, 64 male). While 18 (16\%) was left-sided, 33 (29.5\%) was right-sided MT, and bilateral MT was found in $61(54.5 \%)$ of the cases. No significant statistical difference was found in accordance to gender ( $p>0.05)$ (Tables 1,2$)$.

The concomitant presence of CBs and NSD was in 64 cases. There wasn't any statistically significant relationship between the presence of $C B$ and NSD $(p>0.05)$. No statistically significant differences found between types of CB and OMD ( $p>0.05$ ) (Table 3).

Concha bullosa and mucosal thickening: Fifty of the right-sided $\mathrm{CBs}$ also presented right-sided MS. Twenty- four of the left-sided CBs also presented leftsided MT. In addition, 15 of the subjects with bilateral $\mathrm{CB}$ had bilateral MT. MT was seen more often in cases with lamellar type CB (73.3\%). There wasn't any statistically significant relationship between MT and CB ( $p>0.05$ ) (Table 3).

Nasal septal deviation and mucosal thickening: Thirty-three of the right-sided NSDs had ipsilateral MT. Twenty- seven left-sided NSDs, had also ipsilateral MT. There was no statistically significant difference between NSD and MT ( $p>0.05$ ) (Table 3).

Osteomeatal complex disease and mucosal thickening: Aamong the 9 right-sided OMDs, 8 had ipsilateral MT. On the other hand, of 6 of 7 leftsided OMDs had ipsilateral MT. Additionally 9 of 10 bilateral OMDs also were presenting MT. There was a statistically significant relationship between OMD and MT ( $p=0.00)$ (Table 3). 


\begin{tabular}{|l|l|l|l|l|l|}
\hline \multicolumn{2}{|l|}{ Table 3. Statistical analyse of the evaluated parameters } \\
\hline & MT & CB & OMD & OL & SD \\
\hline MT & - & 0.31 & $0.000^{*}$ & $0.000^{*}$ & 0.37 \\
\hline CB & 0.31 & - & 0.102 & 0.624 & 0.563 \\
\hline OMD & $0.000^{*}$ & 0.102 & - & 0.906 & 0.104 \\
\hline OL & $0.000^{*}$ & 0.624 & 0.906 & - & 0.268 \\
\hline SD & 0.37 & 0.563 & 0.104 & 0.268 & - \\
\hline $\begin{array}{l}\text { *Correlation is significant at the } 0.01 \text { level. MT: Mucosal thickening, CB: Concha bullosa, OMD: Osteomeatal complex disease, OL: Odontogenic lesion, } \\
\text { SD: Septal deviation }\end{array}$
\end{tabular}

Mucosal thickening and odontogenic lesion: Fourteen of the 16 right-sided OLs had right-sided MT, 7 of the 8 left-sided OLs had also left-sided MT, and additionally, 13 of the 15 subjects with bilateral OL had also bilateral MT. There was statistically significant relationship between $\mathrm{MT}$ and $\mathrm{OL}(\mathrm{p}=0.00)$ (Table 3$)$.

\section{Discussion}

MS is an inflammation of maxillary sinuses caused by mucociliary transport failure, related to numerous factors, such as anatomic malformations (NSD, CB), OLs, immune deficits, allergic reactions, smoking, atmospheric pollution, sinonasal polyposis, etc. (2$7,12,18,19)$. Maxillary sinus MT is the radiographical appearance of MS (20). Preoperative evaluation of these factors is important, as it helps to identify potential candidates for surgical procedure and the exact treatment of MS (21).

$\mathrm{CB}$ is the most common variation of the nasal cavity and is most often found in the middle concha $(20,22)$. CB prevalence was reported in the earlier studies $(13,20)$ to range from $14-53 \%$ to $35-53 \%$. Tsai et al. (23) and Yiğit et al. (24) reported the CB ratio of $31.5 \%$ and $25 \%$, respectively. Presence of bilateral CB reported to range from $45 \%$ to $61.5 \%$ in extant studies $(22,25)$. Tunçyürek et al. (12) reported lamellar CB in $25.3 \%$ of the examined cases, bulbous $C B$ in $6.2 \%$, and extensive type of $C B$ in $11.1 \%$ of the cases. Subramanian et al. (26) and Smith et al. (16) reported that CB was seen more frequently in females. This is in harmonious with our results, as most subjects with $\mathrm{CB}$ were female. In our study while the ratio of lamellar CB (25\%) was similar with previous studies, the percentages of bulbous (12.12\%) and extensive CBs $(2.02 \%)$ were different.
NSD is the most frequent deformity of the nasal structures. In the extant literature, its incidence is varying from 40 to $45 \%(24,25)$. In our study, the ratio of cases with NSD $(59.5 \%)$, is higher than the ones found in the study conducted by Smith et al. (16) (19.4\%), and lower than those reported by Stallman et al. (13) (65\%) and Subramanian et al. (26) (62.9\%). Although some researchers indicated a relationship between NSD and large CB, the association between them is still unclear $(14,25)$. The concomitant existence of NSD and CB was reported as $44.6 \%$ by Hatipoğlu et al. (20). On the other hand, Yiğit et al. (24) revealed the incidence of CB in to $18.95 \%$ in nonNSD subjects and $45.34 \%$ in NSD subjects. With a ratio of $53.38 \%$, our study revealed a higher incidence of concomitant presence of CB and NSD. Regional differences and genetic factors could be responsible for these paranasal variatons.

The relationship between NSD and MT is also still unclear (24). In CT studies, Tunçyürek et al. (12) and Smith et al. (16) could not establish an exact association between them. In a study, severe NSD was reported as a predisposing factor for MT (4). In another CT study, Hatipoğlu et al. (20) pointed out a relationship between the cases with severe NSD and existence of MT. In the present study, no statistically significant relationship was found between NSD and MT ( $p>0.05)$.

It is important to investigate the relationship of MT with the presence/absence of $C B$, reverse curvatured concha, and $\mathrm{OMD}$. $\mathrm{CB}$, especially when accompanied with pneumatization of the lower section, constitutes a predisposing factor for the development of OMD. The occurance of the sinus diseases by the block ventilation and mucociliary clearance of the maxillary sinuses caused by the pressure of $O M D$ and $C B$ to the middle meatus, infundibulum, uncinated process 
was asserted $(3,11,12)$. Also it was suggested that the presence of $C B$ prevented appropriate airflow and predisposed the sinus diseases. Contrary findings were also reported $(12,13,27-29)$. For example, Lee et al. (15) reported a case with massive CB which resulted in an OMD and caused right-sided MS. Yousem and David (14) pointed out that CB of a greater size could lead to MT. Contrary to this data, Stallman et al. (13) found no significant relationship between the size of $\mathrm{CB}$ and $\mathrm{MT}$, as $78 \%$ of subjects had MT without $\mathrm{CB}$ (13). No relationship among NSD, CB and MT was stated in our study $(p>0.05)$.

OMS is an inflammatory disease caused by the extent of apical inflammations due to proximity of tooth apexes into the sinus. Mucous membrane of maxillary sinus changes and adjacent OLs can be defined by CBCT images. OMS comprises about 10$12 \%$ of all MS cases and some studies determined its prevalence as ranging from $10 \%$ to $86 \%$ (21). Lu et al. (30), stated that $26 \%$ of subjects with maxillary sinus MT had also periapical lesions. In another study, 72.6 $\%$ of cases with MT also found in relationship with adjacent periapical infection and had changes in the maxillary sinus floor (31). Correspondingly, higher ratio of relationship between $\mathrm{OL}$ and MT was found in our study.

The diagnosis of MS should include clinical examination (dental examination, nasal endoscopic examination) and CT of paranasal sinuses $(9,21)$. Cost and radiation dose from CBCT are substantially lower than the pertaining to $\mathrm{CT}$, but are higher compared to traditional imagining techniques (3133). СBCT provides advanced imagining opportunities of paranasal region with isotropic voxel size and high resolution images. Mucosal changes of sinuses, dimension of OLs, paranasal region abnormities and anatomic structures can be easily detected and evaluated by examining CBCT images (34).

Sinus membrane elevation or "sinus lift" is a significant procedure before dental implant placement (35). Preoperative CBCT examination allows evaluation of MT and residual ridge heights. Before sinus lift surgery, MT should be determined, because greater MT than $5 \mathrm{~mm}$ can be related with OMD as well as MS (36).

\section{Study Limitations}

Lack of clinical conditions and exact history of paranasal problems of the patients whose CBCT images were used are the limitations of our study. There is no previous CBCT study evaluated all parameter's relationships with each other. The main aim of this study is to give an idea about the utilization of the $\mathrm{CBCT}$ in the examination of the paranasal region.

\section{Conclusion}

Our results did not show statistically significant relationship MT and NSD, CB, OMD except OL. Maybe with future studies showing clinical conditions may give more accurate and compherensive statements about this relationship. Despite limitations, our findings showed that identification of MT by CBCT imaging could help to identify the reasons behind MS. CBCT examination enables diagnosis of mucosal changes in maxillary sinuses, as well as variations of paranasal structures and spread of OLs. Thus, CBCT imaging could also be a diagnostic tool for assessment of the NSD, CB, OMD, and $\mathrm{OL}$ and their potential relationship with $\mathrm{MT}$.

\section{Ethics}

Ethics Committee Approval: The Ethical Committee of the Erciyes University (approval no: 2017/440, date: 15.09.2017).

Informed Consent: It was not taken.

Peer-review: Externally peer-reviewed.

\section{Authorship Contributions}

Surgical and Medical Practices: E.K., Concept: E.K., Design: E.K., Data Collection or Processing: D.G.B., E.K., Analysis or Interpretation: E.M.C., E.K., Literature Search: D.G.B., E.K., Writing: E.M.C., E.K.

Conflict of Interest: No conflict of interest was declared by the authors.

Financial Disclosure: The authors declared that this study received no financial support.

\section{References}

1. Lechien JR, Filleul O, Costa de Araujo P, Hsieh JW, Chantrain G, Saussez S. Chronic maxillary rhinosinusitis of dental origin: A systematic review of 674 patient cases. Int J Otolaryngol 2014; 2014: 465173.

2. Brisolla ADOP. Chronic maxillary sinusitis associated with dental impression material. Med Oral Patol Oral Cir Bucal 2009; 14: 163-6.

3. Zinreich SJ, Mattox DE, Kennedy DW, Chisholm HL, Diffley DM, Rosenbaum AE. Concha bullosa: CT evaluation. J Comput Assist Tomogr 1988; 12: 778-84.

4. Rode M, Podboj J, Kogoj-Rode M. Sinus maxillaries mycetoma of odontogenic origin: case report. Braz Dental J 2004; 15: 248-50. 
5. Newman LJ, Platts-Mills TA, Phillips CD, Hazen KC, Gross CW. Chronic sinusitis: relationship of computed tomographic findings to allergy, asthma, and eosinophilia. JAMA 1994; 271: 363-7.

6. Krause HF. Allergy and chronic rhinosinusitis. Otolaryngol Head Neck Surg 2003; 128: 14-6.

7. Kretzschmar DP, Kretzschmar JL. Rhinosinusitis: review from a dental perspective. Oral Surg Oral Med Oral Pathol Oral Radiol Endod 2003; 96: 128-35.

8. Arias Irimia O, Barona Dorado C, Santos Marino JA, Martínez Rodríguez N, Martínez-González JM. Meta-analysis of the etiology of odontogenic maxillary sinusitis. Med Oral Patol Oral Cir Bucal 2010; 15: 70-3.

9. Tomomatsu N, Uzawa N, Aragaki T, Harada K. Aperture width of the osteomeatal complex as a predictor of successful treatment of odontogenic maxillary sinusitis. Int J Oral Maxillofac Surg 2014; 43: 1386-90.

10. Bell GW, Joshi BB, Macleod RI. Maxillary sinus disease: diagnosis and treatment. Br Dent J 2011; 210: 113-8.

11. Bolger WE, Parsons DS, Butzin CA. Paranasal sinus bony anatomic variations and mucosal abnormalities: CT analysis for endoscopic sinus surgery. Laryngoscope 1991; 101: 56-64.

12. Tunçyürek Ö, Eyigör $H$, Songu $M$. The relationship among concha bullosa, septal deviation and chronic rhinosinusitis J Med Updates 2013; 1: 1-7.

13. Stallman JS, Joao NL, Peter MS. The incidence of concha bullosa and its relationship to nasal septal deviation and paranasal sinus disease. AJNR Am J Neuroradiol 2004; 252: 1613-8.

14. Yousem, David M. Imaging of sinonasal inflammatory disease. Radiology. 1993; 188: 303-14.

15. Lee JS, Ko IJ, Kang HD, Lee HS. Massive concha bullosa with secondary maxillary sinusitis. Clin Exp Otorhinolaryngol 2008; 1: 221-3.

16. Smith KD, Edwards PC, Saini TS, Norton NS. The prevalence of concha bullosa and nasal septal deviation and their relationship to maxillary sinusitis by volumetric tomography. Int J Dent 2010; 2010. pii: 404982.

17. Lu Y, Liu Z, Zhang L, Zhou X, Zheng Q, Duan X, Zheng G, et al. Associations between maxillary sinus mucosal thickening and apical periodontitis using cone-beam computed tomography scanning: a retrospective study. J Endod 2012; 38: 1069-74.

18. Endam LM, Cormier C, Bossé $Y$, Filali-Mouhim A, Desrosiers M. Association of IL1A, IL1B, and TNF gene polymorphisms with chronic rhinosinusitis with and without nasal polyposis: a replication study. Arch Otolaryngol Head Neck Surg 2010; 136: 187-92.

19. Tammemagi CM, Davis RM, Benninger MS, Holm AL, Krajenta R. Secondh and smoke as a potential cause of chronic rhinosinusitis: a case-control study. Arch Otolaryngol Head Neck Surg 2010;1 36: 327-34.

20. Hatipoğlu HG, Cetin MA, Yüksel E. Concha bullosa types: their relationship with sinusitis, ostiomeatal and frontal recess disease. Diagn Interv Radiol 2005; 11: 145-9.
21. Deosthale NV, Khadakkar SP, Singh B, Harkare VV, Dhoke PR, Dhote K S. Anatomical variations of Nose and Paranasal Sinuses in Chronic Rhinosinusitis. PSJR 2014; 7: 2.

22. Zinreich SJ, Kennedy DW, Rosenbaum AE, Gayler BW, Kumar AJ, Stammberger $\mathrm{H}$. Paranasal sinuses: $\mathrm{CT}$ imaging requirements for endoscopic surgery. Radiology 1988; 12: 778-4.

23. Tsai TL, Lan MY, Ho CY. There is no structural relationship between nasal septal deviation, concha bullosa, and paranasal sinus fungus balls. Scientific World Journal 2012; 2012: 181246.

24. Yiğit Ö, Acıoğlu E, Çakır, ZA, Şişman AS, Barut AY. Concha bullosa and septal deviation. Eur Arch Otorhinolaryngol 2010; 267: 1397-401.

25. A Tonai, S Baba. Anatomic variations of the bone in sinonasal CT. Acta Otolaryngol 1996; 525: 9-13.

26. Subramanian S, Lekhraj RG, Wong EF, Mastura S, Razi A.Concha bullosa in chronic sinusitis. Med J Malaysia 2005; 60: 535-9.

27. Calhoun KH, Waggenspack GA, Simpson CB, Hokanson JA, Bailey BJ. CT evaluation of the paranasal sinuses in symptomatic and asymptomatic populations. Otolaryngology--head and neck surgery: JAMA Otolaryngol Head Neck Surg 1991; 104: 480-3.

28. Lam WWM, Liang EY, Woo JKS, Van Hasselt A, Metreweli C. The etiological role of concha bullosa in chronic sinusitis. Eur Radiol 1996; 6: 50-2.

29. Unlu HH, Akyar S, Caylan R, Nalca Y. Concha bullosa. J Otolaryngol 1994; 23: 23-7.

30. Lu Y, Liu Z, Zhang L, Zhou X, Zheng Q, Duan X, Zheng G, Wang $H$, Huang $D$. Associations between maxillary sinus mucosal thickening and apical periodontitis using cone-beam computed tomography scanning: a retrospective study. J Endod 2012; 38: 1069-74.

31. Maillet M, Bowles WR, McClanahan SL, John MT, Ahmad M. Cone-beam computed tomography evaluation of maxillary sinusitis. J Endod 2011; 37: 753-75.

32. Halicioglu K, Celikoglu M, Buyuk SK, Sekerci AE, Ucar FI, Yavuz I. Three-dimensional evaluation of the mandibular third molars' development in unilateral crossbite patients: A cone beam computed tomography study. Eur J Dent 2014; 8: 389-94.

33. Nur BG, Ok E, Altunsoy M, Aglarci OS, Colak M, Gungor E. Evaluation of the root and canal morphology of mandibular permanent molars in a south-eastern Turkish population using cone-beam computed tomography. Eur J Dent 2014; 8: 154.

34. Roberts JA, Drage NA, Davies J, Thomas DW. Effective dose from cone beam CT examinations in dentistry. Br J Radiol 2009; 82: 35-40.

35. Ritter L, Lutz J, Neugebauer J, Scheer M, Dreiseidler T, Zinser MJ, et al. "Prevalence of pathologic findings in the maxillary sinus in cone-beam computerized tomography." Oral Surg Oral Med Oral Pathol Oral Radiol Endod 2011; 111: 634-40.

36. Carmeli G, Artzi Z, Kozlovsky A, Segev Y, Landsberg R. Antral computerized tomography pre-operative evaluation: relationship between mucosal thickening and maxillary sinus function. Clin Oral Implants Res 2011; 22: 78-82. 